ORIGINAL ARTICLE

\title{
First record of the chemical composition of essential oil of Piper bellidifolium, Piper durilignum, Piper acutilimbum and Piper consanguineum from the Brazilian Amazon forest
}

\author{
Carolina Alves de ARAUJO ${ }^{1}$, Claudio Augusto Gomes da CAMARA ${ }^{1 *}$, Marcilio Martins de MORAES ${ }^{1}$, \\ Geraldo José Nascimento de VASCONCELOS ${ }^{2}$, Marta Regina Silva PEREIRA33, Charles Eugene ZARTMAN ${ }^{3}$ \\ Universidade Federal Rural de Pernambuco, Departamento de Química. Rua Dom Manoel de Medeiros s/n, CEP 52171-030 Recife, PE, Brasil \\ Universidade Federal do Amazonas, Campus ICET. Rua Nossa Senhora do Rosário, 3863, Tiradentes, CEP 69103-128, Itacoatiara, Amazonas, Brasil \\ 3 Instituto Nacional de Pesquisa da Amazônia, Coordenação de Biodiversidade. Av. André Araújo, 2936, Petrópolis, CEP 69060-001, Manaus, Amazonas, Brasil \\ *Corresponding author: claudio_agc@hotmail.com
}

\begin{abstract}
Piper bellidifolium, Piper durilignum, Piper acutilimbum and Piper consanguineum are bushes that occur in the Amazon and are morphologically similar. With the aim of analyzing the chemical profile of the volatile constituents of these species, essential oils from the leaves were obtained through steam distillation and analyzed using gas chromatography-flame ionization detection (GC-FID) and gas chromatograph coupled to a mass spectrometer (GC-MS). The chemical analysis enabled the identification of 95 compounds representing $96.3 \pm 0.6 \%$ of the P. bellidifolium oil, $95.5 \pm 0.71 \%$ of the $P$. durilignum oil, 98.0 $\pm 1.0 \%$ of the $P$. acutilimbum oil and $96.1 \pm 2.1 \%$ of the $P$. consanguineum oil. Although sesquiterpenes were the predominant chemical class in the oils of the four species, qualitative and quantitative differences were found in their chemical composition. The major constituents were $(E)$-nerolidol $(20.3 \pm 0.4 \%)$ in the $P$. bellidifolium oil, germacrene $\mathrm{D}(11.1 \pm 0.3 \%)$ in the $P$. durilignum oil, and $\gamma$-eudesmol in both the $P$. consanguineum $(18.6 \pm 0.5 \%)$ and $P$. acutilimbum $(7.5 \pm 0.4 \%)$ oils. Despite their morphological similarity, a principal component analysis (PCA) of the GC-MS data clearly separated the four species according to the chemical profile of the essential oil extracted from their leaves.
\end{abstract}

KEYWORDS: Amazon biome, Piper ssp, (E)-Nerolidol, Germacrene D, $\gamma$-Eudesmol

\section{Primeiro registro da composição química de óleos essenciais de Piper bellidifolium, Piper durilignum, Piper acutilimbum e Piper consanguineum da Floresta Amazônica no Brasil}

\section{RESUMO}

Piper bellidifolium, Piper durilignum, Piper acutilimbum e Piper consanguineum são arbustos que ocorrem na Amazônia e são morfologicamente similares. Com o intuito de analisar o perfil químico dos constituintes voláteis dessas espécies, óleos essenciais das folhas foram obtidos por hidrodestilação e analisados por cromatografia gasosa - detector por ionização de chama (CG-FID) e cromatografia gasosa acoplada a espectrometria de massa (CG-EM). A análise química permitiu identificar 95 compostos, representando $96.3 \pm 0.6 \%$ do óleo de $P$. bellidifolium; $95.5 \pm 0.71 \%$ de $P$. durilignum; $98.0 \pm 1.0 \%$ de $P$. acutilimbum e 96.1 $\pm 2.1 \%$ de $P$. consanguineum. Apesar dos óleos das quatro espécies terem sesquiterpeno como classe química predominante, diferenças qualitativas e quantitativas em sua composição química foram observadas. Os principais componentes encontrados foram: $(E)$-nerolidol $(20.3 \pm 0.4 \%)$ em $P$. bellidifolium; germacreno D $(11.1 \pm 0.3 \%)$ em $P$. durilignum; e $\gamma$-eudesmol nos óleos de $P$. consanguineum $(18.6 \pm 0.5 \%)$ e P. acutilimbum $(7.5 \pm 0.4 \%)$. Apesar da similaridade morfológica entre as espécies, uma análise de componentes principais (PCA) dos dados de CG-EM claramente separou as quatro espécies quanto ao perfil químico do óleo essencial extríado de suas folhas.

PAlaVRAS-ChaVE: bioma Amazônia, Piper ssp, (E)-Nerolidol, Germacreno D, $\gamma$-Eudesmol

CITE AS: Araujo, C.A. de; Camara, C.A.G. da; Moraes, M.M. de; Vasconcelos, G.J.N. de; Pereira, M.R.S.; Zartman, C.E. 2018. First record of the chemical composition of essential oil of Piper bellidifolium, Piper durilignum, Piper acutilimbum and Piper consanguineum from in the Brazilian Amazon forest. Acta Amazonica 48: 330-337. 


\section{INTRODUCTION}

Piperaceae is considered one of the most basal clades among angiosperms encountered in tropical and subtropical regions (Frodin 2004). Among the genera belonging to the family, Piper is by far the largest, with nearly 2000 species found in both hemispheres in tropical and temperate regions (Machado 2007; Quijano-Abril et al. 2006). In Brazil, approximately 290 species occur throughout the country, with a greatest representation in the equatorial north, as demonstrated by the 136 species with registered occurrences in the state of Amazonas (Guimarães et al. 2017). However, different authors report an excessive and unproven multiplication of species names for Piper, which hinders an objective evaluation of the true number of species of the genus (Ruschel 2004).

The leaves of many species of Piper are used in folk medicine in the form of infusions for the treatment of ailments and also have economic importance due to their culinary uses and the production of essential oils (Gogosz et al. 2012). Phytochemical investigations of different Piper species and plant parts have led to the isolation of numerous active components, such as alkaloids, flavonoids, lignans and essential oils (Santana et al. 2015; Morais et al. 2007). These oils are basically composed of phenylpropanoids, such as safrole, dillapiole and myristicin, and/or terpenes, such as limonene, $\beta$-caryophyllene, spathulenol, $(E)$-nerolidol, bicyclogermacrene and $\alpha$-cadinol (Guerrini et al. 2009; Santos et al. 2001; Maia and Andrade 2009). Investigations of the biological properties of essential oils from this genus have revealed antimicrobial (Oliveira et al. 2016), antioxidant (Woguem et al. 2013), acaricidal (Araújo et al. 2012) and insecticidal activities (Santana et al. 2015).

According to Guimarães et al. (2017), approximately $80 \%$ of the species of Piper registered for the Brazilian state of Amazonas have not been submitted to studies on the chemical composition of their essential oils. Such is the case of $P$. acutilimbum C. DC., P. consanguineum (Kunth) Trel. \& Yunck., P. durilignum C. DC. and P. bellidifolium Yunck., which occur in the municipalities of Rio Preto da Eva and Manaus in the state of Amazonas and are popularly known as long pepper (pimenta longa) and monkey pepper (pimenta de macaco) due to the length of their inflorescences. These plants are bushes that are morphologically quite similar. Despite this morphological similarity, there are no synonyms described for these species.

As part of a survey of the aromatic flora of Amazonia, this work offers the first description of the chemical composition of essential oils from leaves of the species P. acutilimbum, $P$. consanguineum, $P$. durilignum and $P$. bellidifolium.

\section{MATERIAL AND METHODS}

\section{Collection of plant material}

The fresh leaves of Piper acutilimbum C.DC. and Piper durilignum C.DC. were collected in Rio Preto da Eva, metropolitan region of Manaus (0244’00”S, 5947’26”W).
Piper bellidifolium Yunk. was collected in Itacoatiara, metropolitan region of Manaus (0301'42”S, 5842'37”W). Piper consanguineum (Kunth) Trel. \& Yunck. was collected in the Adolpho Ducke Reserve in Manaus, Amazonas (02 57'18”S, 5955'41”W). Samples were taken from three individual plants of each species. The plants were identified by botanist Marta Regina Silva Pereira, of Instituto Nacional de Pesquisas da Amazônia (INPA). Vouchers of samples were mounted and deposited in the INPA herbarium, under numbers 673 (Piper acutilimbum), 680 (Piper consanguineum), 674 (Piper durilignum) and 694 (Piper bellidifolium).

\section{Chemicals}

All monoterpenes ( $\beta$-Pinene, Limonene, 1,8-Cineole, Terpinolene, Terpinen-4-ol e $\alpha$-Terpineol), and sesquiterpenes ( $\alpha$-Copaene, $\beta$-Caryophyllene, Aromadendrene, $\alpha$-Humulene, Germacrene D, (E)-Nerolidol and Spathulenol) were purchased from Sigma-Aldrich - Brazil and used for coinjetion to confirm the chemical identification.

\section{Essential oil extraction and GC-FID analysis}

The essential oils from fresh leaves $(100 \mathrm{~g}$ from each of three plants of each species), were separately isolated using a modified Clevenger-type apparatus and hydrodistillation for $2 \mathrm{~h}$. The oil layers were separated and dried over anhydrous sodium sulfate, stored in hermetically sealed glass containers, and kept at low temperature $\left(-5^{\circ} \mathrm{C}\right)$ until analysis. Total oil yields were expressed as percentages (grams of oil per grams of fresh plant material). Quantitative GC (500 GC, PerkinElmer Clarus, Shelton, CO, USA) analyses were carried out using an apparatus equipped with a flame ionization detector (FID) and a non-polar DB-5 fused silica capillary column (30 m x $0.25 \mathrm{~mm} \times 0.25 \mu \mathrm{m}$ film thickness) (J \& W Scientific). The oven temperature was programmed from 60 to $240{ }^{\circ} \mathrm{C}$ at a rate $3{ }^{\circ} \mathrm{C} \mathrm{min}^{-1}$. Injector and detector temperature was 260 ${ }^{\circ} \mathrm{C}$. Hydrogen was used as the carrier gas at a flow rate of 1 $\mathrm{mL} \mathrm{min}^{-1}$ in split mode $(1: 30)$. The injection volume was 0.5 $\mu \mathrm{L}$ of diluted solution (1/100) of oil in $n$-hexane. The amount of each compound was calculated from GC-FID peak areas in the order of DB-5 column elution and expressed as a relative percentage of the total area of the chromatograms. All analyses were carried out in triplicate.

\section{GC-MS analysis}

The qualitative gas chromatography-mass spectrometry (GCMS) (220-MS IT GC, Varian, Walnut Creek, CA, USA) analyses were carried out using a system with a mass selective detector, mass spectrometer in EI $70 \mathrm{eV}$ with a scan interval of $0.5 \mathrm{~s}$ and fragments from 40 to $550 \mathrm{Da}$ fitted with the same column and temperature program as that for the GC-FID analyses, with the following parameters: carrier gas = helium; flow rate $=1 \mathrm{~mL} \mathrm{~min}^{-1}$; split mode (1:30); injected volume = $1 \mu \mathrm{L}$ of diluted solution $(1 / 100)$ of oil in $n$-hexane. 


\section{Identification of components}

Identification of the components was based on GC-MS retention indices with reference to a homologous series of C8-C40 n-alkanes calculated using the Van der Dool and Kratz equation (Van den Dool and Kratz 1963) and by computer matching against the mass spectral library of the GC-MS data system (NIST 14 and WILEY 11th) and co-injection with authentic standards as well as other published mass spectra (Adams 2007). Area percentages were obtained from the GC-FID response without the use of an internal standard or correction factors.

\section{Principal component analysis}

Principal component analysis (PCA) based on the complete data set (all parameters measured and the three independent samples for each species) was conducted to evaluate the chemical variation of essential oils within and among the four species. The GC-MS data were exported in ASCII format to Microsoft Excel to produce a data matrix of sample versus metabolite peak with associated peak areas. All the analyses were performed using the Unscrambler software version 9.5 (CAMO Process AS, Norway, 1996-2007).

\section{RESULTS}

The steam distillation of the leaves yielded yellowish oils with critic aromas. The greatest yield was achieved with $P$. consanguineum $(0.30 \pm 0.02 \%)$, followed by $P$. acutilimbum $(0.18 \pm 0.01 \%), P$. durilignum $(0.12 \pm 0.00 \%)$ and $P$. bellidifolium $(0.01 \pm 0.00 \%$ ) (Table 1$)$.

The GC-MS analysis enabled the identification of 95 compounds representing $96.3 \pm 0.6 \%$ of the chemical composition of the oil from P. bellidifolium, $95.5 \pm 0.71 \%$ of $P$. durilignum, $98.0 \pm 1.0 \%$ of $P$. acutilimbum and $96.1 \pm$ $2.1 \%$ of $P$. consanguineum. All Piper oils were composed of monoterpenes and sesquiterpernes. Piper bellidifolium (95.1 $\pm 0.5 \%)$, P. durilignum (72.2 $\pm 0.3 \%)$, P. acutilimbum ( $97.3 \pm$
$1.1 \%)$ and $P$. consanguineum $(95.5 \pm 0.4 \%)$ oils were mainly composed of sesquiterpenes (Table 1).

Forty-one constituents were identified for the $P$. bellidifolium oil, in which $(E)$-nerolidol $(20.3 \pm 0.4 \%)$ was the major constituent, followed by aromadendrene $(13.3 \pm$ $0.3 \%)$ and $\alpha$-copaene $(10.9 \pm 0.2 \%)$. Hinesol $(5.7 \pm 0.1 \%)$, longifolene $(5.4 \pm 0.1 \%)$ and $\beta$-acoradiene $(5.0 \pm 0.1 \%)$ were also found in significant quantities in this oil (Table 1). With 47 constituents identified, representing $98.0 \pm 1.0 \%$ of the total, the P. acutilimbum oil had the largest percentage of sesquiterpenes $(97.3 \pm 1.1 \%)$. The major constituents were $\gamma$-eudesmol $(7.5 \pm 0.4 \%)$, germacrene B $(6.9 \pm 1.7 \%)$, $\alpha$-muurolol (6.4 $\pm 0.1 \%), \beta$-longipinene $(6.2 \pm 0.1 \%)$ and 1 -epi-cubenol $(5.6 \pm 0.2 \%)$. Forty compounds were identified, representing $96.1 \pm 2.1 \%$ of the $P$. consanguineum oil. The most abundant compound was $\gamma$-eudesmol $(18.6 \pm 0.5 \%)$, followed by $\gamma$-cadinene $(11.3 \pm 0.1 \%),(E)$-nerolidol $(6.2 \pm$ $0.0 \%)$ and $\alpha$-muurolol $(5.0 \pm 0.2 \%)$. Thirty-eight compounds were identified in the $P$. durilignum oil, the major constituents of which were germacrene $\mathrm{D}(11.1 \pm 0.3 \%)$, limonene (10.7 $\pm 0.5 \%)$ and $\beta$-caryophyllene $(9.1 \pm 0.2 \%)$. This oil had the highest percentage of monoterpenes among the oils analyzed $(23.3 \pm 0.5 \%)$. Other constituents were also identified in quantities higher than 5\%: (E)-nerolidol (6.2 $\pm 0.2 \%)$, epi$\alpha$-cadinol $(5.2 \pm 0.1 \%)$ and linalool $(5.1 \pm 0.1 \%)$.

$\gamma$-Eudesmol was found in a greater proportion in the $P$. consanguineum oil $(18.6 \pm 0.5 \%)$, followed by $P$. acutilimbum $(7.5 \pm 0.4 \%)$, P. bellidifolium $(2.3 \pm 0.0 \%)$ and $P$. durilignum $(0.9 \pm 0.0 \%)$. Germacrene $\mathrm{D}$ was found in a greater proportion in the $P$. durilignum oil $(11.1 \pm 0.3 \%)$ and at less than $4 \%$ in the other species. 9-Epi-(E)-caryophyllene and allo-aromadendrene epoxide were found at less than $3 \%$ in all species.

The PCA grouped the samples closely within species and separated the samples clearly among the four species (Figure 1). Seventy-two percent of the variability in the data was explained by the first $(\mathrm{PC} 1=47 \%)$ and second $(\mathrm{PC} 2=25 \%)$ components.

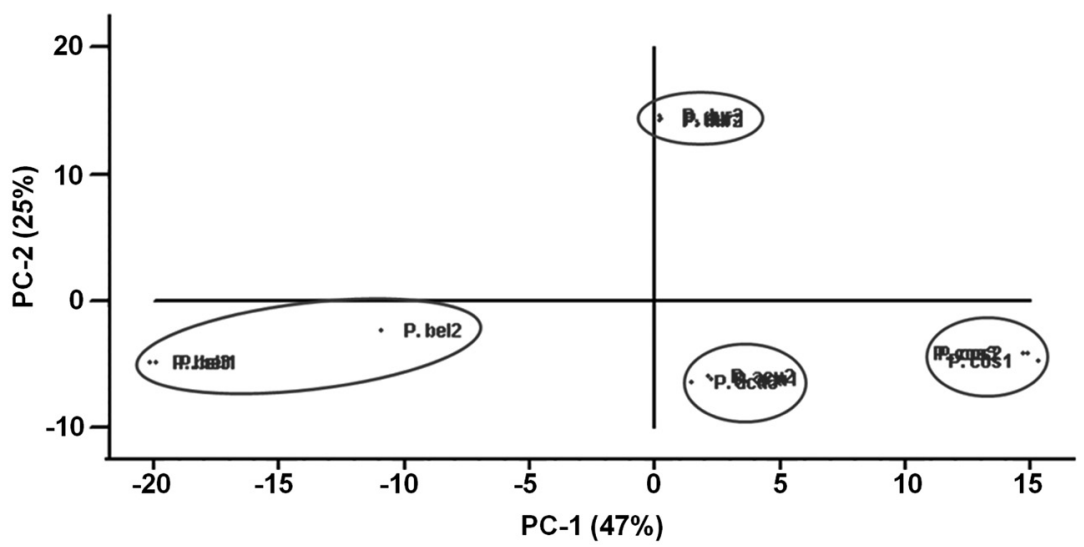

Figure 1. Principal component analysis scores (PC1 and PC2) of the GC-MS of essential oil of leaves of P. bellidifolium (P.bel), P. durilignum (P.dur), P. acutilimbum (P.acu) and $P$. consanguineum (P.cos). 
Table 1. Percentage composition yield of essential oils from leaves of Piper bellidifolium (P.bel), Piper durilignum (P.dur), Piper acutilimbum (P.acu) and Piperconsanguineum (P.con).

\begin{tabular}{|c|c|c|c|c|c|c|}
\hline Compound & $\mathrm{Rl}^{\mathrm{a}}$ & $\mathrm{Rl}^{\mathrm{b}}$ & P.bel & P.dur & P.acu & P.con \\
\hline Yield (\%) $\pm S D$ & & & $0.01 \pm 0.00$ & $0.12 \pm 0.00$ & $0.18 \pm 0.01$ & $0.30 \pm 0.02$ \\
\hline$a$-Thujene & 929 & 924 & -- & $2.0 \pm 0.1$ & -- & -- \\
\hline$\beta$-Pinene* & 974 & 974 & -- & $5.0 \pm 0.1$ & -- & -- \\
\hline$\delta$-3-Carene & 1006 & 1008 & $0.3 \pm 0.0$ & -- & -- & -- \\
\hline Limonene* & 1022 & 1024 & $0.5 \pm 0.0$ & $10.7 \pm 0.5$ & -- & -- \\
\hline Terpinolene & 1085 & 1086 & -- & -- & $0.2 \pm 0.0$ & $0.6 \pm 0.0$ \\
\hline Linalool & 1095 & 1095 & $0.3 \pm 0.0$ & $5.1 \pm 0.1$ & -- & -- \\
\hline$a$-Terpineol* & 1180 & 1186 & $0.2 \pm 0.0$ & $0.4 \pm 0.0$ & -- & -- \\
\hline y-Terpineol & 1191 & 1199 & -- & -- & $0.6 \pm 0.0$ & -- \\
\hline Neo-3-Thujanol acetate & 1270 & 1273 & -- & $0.1 \pm 0.0$ & -- & -- \\
\hline a-Cubebene & 1339 & 1345 & $0.3 \pm 0.0$ & -- & $0.1 \pm 0.0$ & -- \\
\hline Cyclosativene & 1358 & 1369 & $0.2 \pm 0.0$ & -- & -- & -- \\
\hline$a-Y l a n g e n e$ & 1370 & 1373 & -- & $4.1 \pm 0.1$ & $0.7 \pm 0.0$ & -- \\
\hline Isoledene & 1374 & 1374 & -- & -- & $0.4 \pm 0.0$ & $1.1 \pm 0.0$ \\
\hline a-Copaene* & 1376 & 1374 & $10.9 \pm 0.2$ & -- & -- & -- \\
\hline$\beta$-Panasinsene & 1381 & 1381 & -- & $5.1 \pm 0.1$ & $0.4 \pm 0.0$ & $1.3 \pm 0.0$ \\
\hline$\beta$-Cubebene & 1386 & 1387 & -- & -- & $0.6 \pm 0.0$ & -- \\
\hline$\beta$-Elemene & 1390 & 1389 & $0.4 \pm 0.0$ & -- & -- & -- \\
\hline$\beta$-Longipinene & 1399 & 1400 & -- & -- & $6.2 \pm 0.1$ & -- \\
\hline Longifoliene & 1405 & 1407 & $5.4 \pm 0.1$ & -- & -- & -- \\
\hline$\beta$-Funebrene & 1413 & 1413 & -- & -- & $0.2 \pm 0.0$ & $1.0 \pm 0.0$ \\
\hline$\beta$-Caryophyllene* & 1417 & 1417 & -- & $9.1 \pm 0.2$ & -- & $0.5 \pm 0.0$ \\
\hline$\beta$-Cedrene & 1421 & 1419 & $0.7 \pm 0.1$ & $0.7 \pm 0.0$ & $0.4 \pm 0.1$ & -- \\
\hline$\beta$-Copaene & 1426 & 1430 & -- & $0.7 \pm 0.0$ & -- & -- \\
\hline a-Trans-bergamotene & 1430 & 1432 & -- & -- & $2.7 \pm 0.0$ & -- \\
\hline$\gamma$-Elemene & 1435 & 1434 & -- & $2.9 \pm 0.0$ & -- & -- \\
\hline a-Guaiene & 1438 & 1437 & -- & -- & $0.3 \pm 0.0$ & $2.0 \pm 0.0$ \\
\hline Aromadendrene* & 1440 & 1439 & $13.3 \pm 0.3$ & $1.6 \pm 0.1$ & -- & $0.6 \pm 0.0$ \\
\hline Cis-Muurola 3,5-diene & 1444 & 1448 & $0.8 \pm 0.0$ & -- & -- & $3.8 \pm 0.1$ \\
\hline$a$-Humulene* & 1447 & 1452 & -- & -- & $0.3 \pm 0.0$ & -- \\
\hline a-Patchoulene & 1449 & 1454 & -- & -- & $0.7 \pm 0.0$ & $1.3 \pm 0.0$ \\
\hline allo-Aromadendrene & 1460 & 1458 & $1.1 \pm 0.1$ & -- & -- & $1.1 \pm 0.0$ \\
\hline Dehydro-Aromadendrane & 1462 & 1460 & $0.5 \pm 0.0$ & -- & -- & -- \\
\hline 9-epi-(E)-Caryophyllene & 1464 & 1464 & $0.3 \pm 0.0$ & $1.2 \pm 0.0$ & $3.0 \pm 0.0$ & $1.0 \pm 0.0$ \\
\hline$\beta$-Acoradiene & 1476 & 1469 & $5.0 \pm 0.1$ & -- & -- & -- \\
\hline$y$-Muurolene & 1480 & 1478 & -- & -- & -- & $1.4 \pm 0.0$ \\
\hline$y$-Himachalene & 1482 & 1481 & $3.7 \pm 0.0$ & -- & $2.6 \pm 0.0$ & $1.1 \pm 0.0$ \\
\hline Germacrene D* & 1484 & 1484 & $1.7 \pm 0.1$ & $11.1 \pm 0.3$ & $0.5 \pm 0.0$ & $3.2 \pm 0.1$ \\
\hline$\beta$-Selinene & 1485 & 1489 & $3.6 \pm 0.1$ & $3.3 \pm 0.1$ & -- & -- \\
\hline Epi-Cubebol & 1498 & 1493 & $0.4 \pm 0.0$ & -- & $3.8 \pm 0.0$ & $0.9 \pm 0.0$ \\
\hline Trans- $\beta$-Guaiene & 1504 & 1502 & $1.1 \pm 0.0$ & $1.6 \pm 0.1$ & -- & -- \\
\hline a-Bulnesene & 1506 & 1509 & -- & -- & $0.6 \pm 0.0$ & -- \\
\hline$y$-Cadinene & 1515 & 1513 & -- & -- & $0.6 \pm 0.0$ & $11.3 \pm 0.1$ \\
\hline (Z)- $\gamma$-Bisabolene & 1515 & 1514 & -- & -- & -- & $0.8 \pm 0.1$ \\
\hline Cubebol & 1516 & 1514 & -- & -- & $1.0 \pm 0.0$ & -- \\
\hline a-Dehydro ar-Himachalene & 1518 & 1516 & -- & -- & $1.4 \pm 0.6$ & -- \\
\hline 7-epi-a-Selinene & 1520 & 1520 & -- & -- & $1.0 \pm 0.1$ & -- \\
\hline Trans-Calamenene & 1523 & 1521 & $0.4 \pm 0.1$ & -- & $1.2 \pm 0.2$ & -- \\
\hline$\delta$-Cadinene & 1523 & 1522 & $0.6 \pm 0.1$ & -- & $4.4 \pm 1.5$ & -- \\
\hline y-Cuprenene & 1534 & 1532 & -- & $0.8 \pm 0.0$ & -- & -- \\
\hline
\end{tabular}


Table 1. Continued.

\begin{tabular}{|c|c|c|c|c|c|c|}
\hline Compound & $\mathrm{Rl}^{\mathrm{a}}$ & $\mathrm{Rl}^{\mathrm{b}}$ & P.bel & P.dur & P.acu & P.con \\
\hline 10-epi-Cubebol & 1534 & 1533 & $0.4 \pm 0.0$ & -- & $3.0 \pm 0.0$ & $1.5 \pm 0.0$ \\
\hline Selina-3-7(11)-diene & 1540 & 1545 & -- & -- & $0.3 \pm 2.4$ & -- \\
\hline Italiene epoxide & 1545 & 1547 & -- & $0.6 \pm 0.1$ & $3.0 \pm 1.3$ & -- \\
\hline Elemol & 1550 & 1548 & -- & $2.4 \pm 0.0$ & $4.1 \pm 2.4$ & -- \\
\hline Germacrene B & 1554 & 1559 & -- & $2.7 \pm 0.0$ & $6.9 \pm 1.7$ & $1.2 \pm 0.1$ \\
\hline (E)-Nerolidol* & 1561 & 1561 & $20.3 \pm 0.4$ & $6.2 \pm 0.2$ & -- & $6.2 \pm 0.0$ \\
\hline Maaliol & 1565 & 1566 & -- & $0.9 \pm 0.0$ & $1.6 \pm 0.4$ & $0.7 \pm 0.1$ \\
\hline Palustrol & 1570 & 1567 & -- & -- & -- & $3.4 \pm 0.2$ \\
\hline Longipinanol & 1571 & 1567 & $1.9 \pm 0.1$ & -- & -- & $1.2 \pm 0.2$ \\
\hline a-Cedrene epoxide & 1573 & 1574 & $3.6 \pm 0.2$ & -- & $0.7 \pm 0.0$ & -- \\
\hline Spathulenol* & 1576 & 1577 & -- & -- & $1.4 \pm 0.0$ & -- \\
\hline Trans-Sesquisabinene hidrate & 1577 & 1577 & -- & -- & $1.6 \pm 0.0$ & -- \\
\hline Himachalene epoxide & 1580 & 1578 & -- & -- & $0.7 \pm 0.1$ & -- \\
\hline Caryophyllene oxide & 1586 & 1582 & -- & -- & $4.2 \pm 0.1$ & -- \\
\hline Globulol & 1595 & 1590 & -- & $1.6 \pm 0.1$ & $1.5 \pm 0.2$ & $3.7 \pm 0.1$ \\
\hline Viridiflorol & 1597 & 1592 & -- & $0.4 \pm 0.0$ & $1.4 \pm 0.3$ & $1.0 \pm 0.1$ \\
\hline Carotol & 1599 & 1594 & -- & -- & $4.6 \pm 0.8$ & $4.2 \pm 0.1$ \\
\hline Longiborneol & 1600 & 1599 & $0.8 \pm 0.0$ & -- & $2.9 \pm 0.1$ & -- \\
\hline Cedrol & 1600 & 1600 & -- & -- & $4.1 \pm 0.1$ & $1.1 \pm 0.0$ \\
\hline Guaiol & 1603 & 1600 & -- & $1.1 \pm 0.1$ & -- & $1.8 \pm 0.0$ \\
\hline Ledol & 1604 & 1602 & -- & $0.6 \pm 0.0$ & -- & -- \\
\hline 1,10-di-epi-Cubenol & 1612 & 1618 & $1.1 \pm 0.1$ & $1.5 \pm 0.1$ & -- & $1.2 \pm 0.0$ \\
\hline$\beta$-Cedrene epoxide & 1625 & 1621 & -- & $0.8 \pm 0.0$ & -- & -- \\
\hline 1-epi-Cubenol & 1631 & 1627 & $1.2 \pm 0.0$ & $0.8 \pm 0.0$ & $5.6 \pm 0.2$ & -- \\
\hline$\gamma$-Eudesmol & 1635 & 1630 & $2.3 \pm 0.0$ & $0.9 \pm 0.0$ & $7.5 \pm 0.4$ & $18.6 \pm 0.5$ \\
\hline epi-a-Cadinol & 1638 & 1638 & -- & $5.2 \pm 0.1$ & -- & -- \\
\hline allo-Aromadendrene epoxide & 1640 & 1639 & $1.3 \pm 0.1$ & $0.9 \pm 0.0$ & $0.6 \pm 0.0$ & $1.2 \pm 0.1$ \\
\hline Hinesol & 1640 & 1640 & $5.7 \pm 0.1$ & -- & -- & -- \\
\hline a-Muurolol & 1650 & 1644 & -- & $1.0 \pm 0.1$ & $6.4 \pm 0.1$ & $5.0 \pm 0.2$ \\
\hline Cubenol & 1652 & 1645 & -- & -- & -- & $1.7 \pm 0.0$ \\
\hline Pogostol & 1656 & 1651 & -- & -- & -- & $1.5 \pm 0.4$ \\
\hline Valerianol & 1660 & 1656 & -- & -- & -- & $1.2 \pm 0.1$ \\
\hline cis-Calamenen-10-ol & 1665 & 1660 & $0.4 \pm 0.0$ & $0.6 \pm 0.0$ & $0.3 \pm 0.1$ & -- \\
\hline Intermedeol & 1668 & 1665 & $0.5 \pm 0.0$ & -- & -- & -- \\
\hline 14-hydroxy (Z)-Caryophyllene & 1670 & 1666 & -- & $0.7 \pm 0.0$ & $0.6 \pm 0.3$ & $4.6 \pm 0.2$ \\
\hline (E)-Bisabol-11-ol & 1672 & 1667 & $0.7 \pm 0.0$ & -- & -- & -- \\
\hline 14-hydroxy-9-epi-(E)-Caryophyllene & 1673 & 1668 & $0.7 \pm 0.0$ & -- & -- & -- \\
\hline Khusinol & 1683 & 1679 & -- & $0.6 \pm 0.0$ & -- & -- \\
\hline Germacra-4(15), 5,10(14)-trien-1-a-ol & 1689 & 1685 & -- & $0.6 \pm 0.0$ & -- & -- \\
\hline (Z)-a-trans-Bergamotol & 1686 & 1690 & $1.4 \pm 0.1$ & -- & -- & -- \\
\hline Eudesm-7(11)-em-4-ol & 1699 & 1700 & $0.7 \pm 0.1$ & -- & -- & -- \\
\hline Amorpha-4,9-dien-2-ol & 1701 & 1700 & $1.2 \pm 0.1$ & -- & -- & -- \\
\hline Cis-Thusopsenal & 1712 & 1708 & $0.2 \pm 0.0$ & -- & -- & $0.1 \pm 0.0$ \\
\hline 14-hydroxy-a-Humulene & 1719 & 1713 & -- & -- & -- & $0.3 \pm 0.0$ \\
\hline Vetiselinenol & 1734 & 1730 & -- & -- & -- & $0.5 \pm 0.1$ \\
\hline Epi-Cyclocolorenone & 1768 & 1774 & -- & -- & -- & $0.9 \pm 0.1$ \\
\hline Monoterpenes & & & $1.2 \pm 0.0$ & $23.3 \pm 0.5$ & $0.7 \pm 0.0$ & $0.6 \pm 0.0$ \\
\hline Sesquiterpenes & & & $95.1 \pm 0.5$ & $72.2 \pm 0.3$ & $97.3 \pm 1.1$ & $95.5 \pm 0.4$ \\
\hline Total & & & $96.3 \pm 0.6$ & $95.5 \pm 0.7$ & $98.0 \pm 1.0$ & $96.1 \pm 0.4$ \\
\hline
\end{tabular}




\section{DISCUSSION}

The yields obtained in this study are in agreement with those reported in the literature for leaf oils from other species of Piper collected in Amazonia. Morais et al. (2007) and Rameshkumar et al. (2011) report yields of $0.01 \%$ for $P$. gaudichaudianum and $0.05 \%$ for $P$. longum, which are similar to that found for P. bellidifolium. Andrade and Zoghbi (2007) report a yield of $0.03 \%$ for $P$. glandulosissimum (0.3\%), which is similar to that found for $P$. consanguineum. The differences in yields among our four species are likely due to the influence of abiotic factors, such as temperature, luminosity, seasonality, nutrition and water availability (Pacheco et al. 2016). Further analyses using samples from a wider geographical scale are necessary to reliably determine the inter-specific variability in leaf oil yield in these species.

There were significant qualitative differences in the chemical profiles among the oils of the four species, as was evident in the PCA analysis. Among the 95 compounds identified, only four were common to all four oils (germacrene D, 9-epi- $(E)$ caryophyllene, $\gamma$-eudesmol and allo-aromadendrene epoxide). The main compounds identified in this study have also been found in other Piper species in different regions of Brazil and the world. For instance, germacrene $\mathrm{D}$ has been found in large quantities in leaf oil of $P$. magnibaccum (40.8\%) from Malaysia (Hashim et al. 2017) and P. pedicellatum (40.80\%) from India (Saika et al. 2015). In Brazil, this sesquiterpene has been identified as a major constituent of the oils from P. regnellii (45.6 to 51.4\%), $P$. umbellatum (55.8\%) and $P$. arboreum (72.87\%), which occur in the states of São Paulo (Anderson et al. 2017; Perigo et al. 2016) and Rondônia (Machado et al. 1994).

(E)-nerolidol, which was the major constituent of the $P$. bellidifolium oil, is also reported to be the major constituent of the leaf oils from $P$. claussenianum (80\%) from the state of Espírito Santo, Brazil (Marques et al. 2017), P. gaudichaudianum (22.06\%) from the state of Rio Grande do Sul, Brazil (Sperotto et al. 2013) and P. flaviforum (40.5\%) from China (Li et al. 2014). $\gamma$-Eudesmol, which was the major constituent of the P. acutilimbum and P. consanguineum oils, has also been reported to be the main component of the leaf oil of $P$. duckei (17.9\%) from the state of Amazonas, Brazil (Carmo et al. 2012), P. arboretum (14.61\%) from the state of Rio de Janeiro, Brazil (Santos et al. 2001) and P. cernuum (11.65\%) from the state of Santa Catarina, Brazil (Gasparetto et al. 2016).

Other constituents found in significant percentages in the Piper oils investigated herein have been characterized as major constituents in leaf oils from several species of the genus collected in all regions of Brazil. For example, $\beta$-caryophyllene, which was identified in $P$. durilignum, has also been found in the leaf oil of P. cyrtopodon (34.6\%) occurring in northern Brazil (Andrade et al. 2006), P. dilatatum (25.03\%) from northeastern Brazil (Cysne et al. 2005), and P. gaudichaudianum (17.4\%) from southern Brazil (Von Poser et al. 1994), as well as in P. arboreum (25.1\%) (Navickiene et al. 2006), P. cernuum (20.69\%) (Costantin et al. 2001) and P. truncatum (24.2\%) (Trindade et al. 2010) from southeastern Brazil. $\beta$-Caryophyllene has also been reported as a major constituent of Piper species in other countries, such as P. longispicum (45.2\%) in Panamá (Santana et al. 2015), P. hispidum (23.6\%) in Colombia (Benitez et al. 2009), P. umbellatum (28.2\%) in Cameroon (François et al. 2009), $P$. chaba (28.6\%) in India (Rameshkumar et al. 2011), and $P$. nigrum (24.34\%) in Malaysia (Bagheri et al. 2014). Limonene, which was found in $P$. durilignum, has been reported as a major constituent of leaf oils from P. vitaceum (33.2\%) in the state of Amazonas, Brazil (Luz et al. 2000) and P. confertinodum (18.3\%) in Colombia (Caballero-Gallardo et al. 2014).

The sesquiterpene $\alpha$-copaene, which was present at over $10 \%$ in the P. bellidifolium oil, has also been reported as a major constituent of $P$. boehmeriafolium oil (28.3\%) from Vietnam (Hieu et al. 2014). Aromadendrene was another sesquiterpene present in significant proportion in $P$. belldifolium and has been reported as a major constituent of the leaf oils of $P$. gaudichaudianum (15.55\%) from the state of Rondônia, Brazil (Morais et al. 2007) and P. muricatum (16.2\%) from Malaysia (Salleh et al. 2015). The sesquiterpene $\gamma$-cadinene has been characterized in the leaf oil of P. hispidum (25.13\%) from the state of Rondônia, Brazil (Machado et al. 1994) and P. cubeba (16.6\%) from Indonesia (Bos et al. 2007) in larger quantities than that found by us in the oil of P. consanguineum.

\section{CONCLUSIONS}

This is the first report of the chemical composition of essential oils from Piper bellidifolium, P. durilignum, P. acutilimbum and $P$. consanguineum occurring in the Amazon region in Brazil. The abundance of sesquiterpenes in the leaf oils from these species is in agreement with the predominant class reported in the literature for species of Piper. The species were clearly differentiated by their qualitative chemical compositions, with only four constituents common to the four species.

\section{ACKNOWLEDGMENTS}

The authors are grateful to the Fundação de Amparo à Ciência e Tecnologia do Estado de Pernambuco (FACEPE), Conselho Nacional de Desenvolvimento Científico e Tecnológico (CNPq), and Coordenaçâo de Aperfeiçoamento de Pessoal de Nível Superior (CAPES) for awarding a grant (CAPES proc. \# IBPG-0984-5.01/10); a productivity scholarship (CNPq, \# $312277 / 2013-0)$, and research funding for this study (CNPq proc. \# 403162/203-0; FACEPE proc. \# APQ-1008-1.06/15; APQ-0476-1.06/14; APQ-08601.06/16). 


\section{REFERENCES}

Adams, R.P. 2007. Identification of Essential Oil Components by Gas Chromatography/Quadrupole Mass Espectroscopy, 4th ed. Allured Publishing Corporation, Carol Stream, Illinois, 804p.

Andrade, E.H.A.; Guimarães, E.F.; da Silva, M.H.L.; Pereira, R.A.; Bastos, C.N.; Maia, J.G.S. 2006. Essential Oil Composition of Piper cyrtopodon (Miq.) C. DC. Journal of Essential Oil Bearing Plants, 9: 53-59.

Andrade, E.H.A.; Zoghbi, M.G.B. 2007. Volatile Constituents of the Leaves and Stems of Piper glandulosissimum Yunck. Journal of Essential Oil Research, 19: 401-402.

Anderson, R.R.; Girola, N.; Figueiredo, C.R.; Londero, V.S.; Lago, J.H.G. 2017. Circadian variation and in vitro cytotoxic activity evaluation of volatile compounds from leaves of Piper regnellii (Miq) C. DC. var. regnellii (C. DC.) Yunck (Piperaceae). Natural Product Research, 3: 1-4.

Araújo, M.J.C.; Da Camara, C.A.G.; Born, F.S.; Moraes, M.M.; Badji, C.A. 2012. Acaricidal activity and repellency of essential oil from Piper aduncum and its components against Tetranychus urticae. Experimental and Applied Acarology, 57: 139-155.

Bagheri, H.; Manap, M.Y.B.A.; Solati, Z. 2014. Response surface methodology applied to supercritical carbon dioxide extraction of Piper nigrum L. essential oil. Food Science and Technology (LEB), 57: 149-155.

Benítez, N.P.; Melendez, E.; Stashenko, E.E. 2009. Composición química y actividad antibacteriana del aceite esencial de hojas de Piper lanceaefolium, planta usada tradicionalmente en Colombia. Boletin Latinoamericano y del Caribe de Plantas, 8: 301-304.

Bos, R.; Woerdenbag, H.J.; Kayser, O.; Quax, W.J. 2007. Essential Oil Constituents of Piper cubeba L. fils. from Indonesia. Journal of Essential Oil Research, 19: 14-17.

Caballero-Gallardo, K.; Pino-Benitez, N.; Pajaro-Castro, N.; Stashenko, E.; Olivero-Verbel, J. 2014. Plants cultivated in Choco, Colombia, as source of repellents against Tribolium castaneum (Herbst). Journal of Asia-Pacific Entomology, 17: 753-759.

Costantin, M.B.; Sartorelli, P.; Limberger, R.; Henriques, A.T.; Steppe, M.; Ferreira, M.J.P.; Ohara, M.T.; Emerenciano, V.P.; Kato, M.J. 2001. Essential Oils from Piper cernuum and Piper regnellii: Antimicrobial Activities and Analysis by GC/MS and ${ }^{13}$ C-NMR. Planta Medica, 67: 771-773.

Carmo, D.F.M.; Amaral, A.C.F.; Machado, G.M.C.; Leon, L.L.; Silva, J.R.A. 2012. Chemical and Biological Analyses of the Essential Oils and Main Constituents of Piper Species. Molecules, 17: 1819-1829.

Cysne, J.B.; Canuto, K.M.; Pessoa, O.D.L.; Nunes, E.P.; Silveira, E.R. 2005. Leaf Essential Oils of Four Piper Species from the State of Ceará - Northeast of Brazil. Journal of the Brazilian Chemical Society, 16: 1378-1381.

Francois, T.; Michel J.D.P.; Lambert, S.M.; Ndifor, F.; Vyry W.N.A.; Henri, A.Z.P.; Chantal, M. 2009. Comparative essential oils composition and insecticidal effect of different tissues of Piper capense L., Piper guineense Schum. et Thonn., Piper nigrum L. and Piper umbellatum L. grown in Cameroon. African Journal of Biotechnology, 8: 424-431.
Frodin, D.G. 2004. History and concepts of big plant genera. Taxon, 53: 753-776.

Gasparetto, A.; Cruz, A.B.; Wagner, T.M.; Bonomini, T.J.; Correa, R.; Malheiros, A. 2016. Seasonal variation in the chemical composition, antimicrobial and mutagenic potential of essential oils from Piper cernuum. Industrial Crops and Products, 95: 256-263.

Guimarães, E.F.; Carvalho-Silva, M.; Monteiro, D.; Medeiros, E. 2017. Piperaceae. In: Lista de espécies da flora do Brasil. Jardim Botânico do Rio de Janeiro. (http://floradobrasil.jbrj.gov.br/ jabot/floradobrasil/FB12735). Accessed on 12/19/2017.

Gogosz, A.M.; Boeger, M.R.T.; Negrelle1, R.R.B.; Bergo, C. 2012. Anatomia foliar comparativa de nove espécies do gênero Piper (Piperaceae). Rodriguésia, 63: 405-417.

Guerrini, A.; Sacchetti, G.; Rossi, D.; Paganetto, G.; Muzzoli, M.; Andreotti, E.; Tognolini, M.; Maldonado, M.E.; Bruni, R. 2009. Bioactivities of Piper aduncum L. and Piper obliquum Ruiz \& Pavon (Piperaceae) essential oils from Eastern Ecuador. Environmental Toxicology and Pharmacology, 27: 39-48.

Hashim, N.A.; Ahmad, F.; Jani, N.A.; Susanti, D. 2017. In vitro Antioxidant, Antityrosinase, Antibacterial and Cytotoxicity Activities of the Leaf and Stem Essential Oil from Piper magnibaccum C. DC. Journal of Essential Oil Bearing Plants, 20: 223-232.

Hieu, L.D.; Thang, T.D.; Hoi, T.M.; Ogunwande, I.A. 2014. Chemical composition of essential oils from four Vietnamese species of Piper (Piperaceae). Journal of Oleo Science, 63: 211-217.

Li, R.; Yang, J.J.; Wang, Y.F.; Sun, Q.; Hu, H.B. 2014. Chemical composition, antioxidant, antimicrobial and anti-inflammatory activities of the stem and leaf essential oils from Piper flaviflorum from Xishuangbanna, SW China. Natural Product Communications, 9: 1011-1014.

Luz, A.I.R.; Silva, J.D.; Zoghbi, M.G.B.; Andrade, E.H.A.; Silva, M.H.I.; Maia, J.G.S. 2000. Volatile Constituents of Brazilian Piperaceae. Part 4. Essential Oil Composition of Piper dactylostigmum, $P$. plurinervosum and $P$. vitaceum. Journal of Essential Oil Research, 12: 94-96.

Machado, S.M.F.; Militão, J.S.L.T.; Facundo, V.A.; Ribeiro, A.; Morais, S.M.; Machado, M.I.L. 1994. Leaf Oils of Two Brazilian Piper Species: Piper arboreum Aublet var. latifolium (CDC) Yuncker and Piper hispidum Sw. Journal of Essential Oil Research, 6: 643-644.

Machado, N.S.O., 2007. Estudo da anatomia foliar de espécies do gênero Piper L. (Piperaceae) no estado do Rio de Janeiro. Doctoral thesis. Universidade Federal do Rio de Janeiro, Rio de Janeiro, Brazil, 103p.

Morais, S.M.; Facundo, V.A.; Bertini, L.M.; Cavalcanti, E.S.B.; Junior, J.F.A.; Ferreira, A.S.; Brito, E.S.; Neto, M.A.S.N. 2007. Chemical composition and larvicidal activity of essential oils from Piper species. Biochemical Systematics and Ecology, 35: 670-675.

Maia, J.G.S.; Andrade, E.H.A. 2009. Database of the Amazon aromatic plants and their essential oils. Quimica Nova, 32: 595-622.

Marques, A.M.; Fingolo, C.E.; Kaplan, M.A.C. 2017. HSCCC separation and enantiomeric distribution of key volatile 
constituents of Piper claussenianum (Miq.) C. DC. (Piperaceae). Food and Chemical Toxicology, 109: 1111-1117.

Navickiene, H.M.D.; Morandim, A.A.; Alécio, A.C.; Regasini, L.O.; Bergamo, D.C.B.; Telascrea, M., et. al. 2006. Composition and Antifungal Activity of Essential Oils from Piper aduncum, Piper arboreum and Piper tuberculatum. Quimica Nova, 29: 467-470.

Oliveira, R.A.; Assis, A.M.A.D.; Silva, L.A.M.; Andrioli, J.L.; Oliveira, F.F. 2016. Chemical profile and antimicrobial activity of essential oil of Piper ilheusense. Chemistry of Natural Compounds, 52: 331-333.

Perigo, C.V.; Torres, R.B.; Bernacci, L.C.; Guimarães, E.F.; Haber, L.L.; Facanali, R.; Vieira, M.A.R.; Quecini, V.; Marques, O.M. 2016. The chemical composition and antibacterial activity of eleven Piper species from distinct rainforest areas in Southeastern Brazil. Industrial Crops and Products, 94: 528-539.

Quijano-Abril, M.A.; Callejas-Posada, R.; Miranda-Esquivel, D.R. 2006. Areas of endemism and distribution patterns for Neotropical Piper species (Piperaceae). Journal of Biogeography, 33: 1266-1278.

Rameshkumar, K.B.; Anu Aravind, A.P.; Mathew, P.J. 2011. Comparative Phytochemical Evaluation and Antioxidant Assay of Piper longum L. and Piper chaba Hunter Used in Indian Traditional Systems of Medicine. Journal of Herbs, Spices \& Medicinal Plants, 17: 351-360.

Ruschel, D. 2004. O Gênero Piper (Piperaceae) no Rio Grande do Sul. Master's dissertation. Universidade Federal do Rio Grande do Sul, Porto Alegre, Brazil. 140p.

Saikia, A.K.; Sarma, S.K.; Strano, T.; Ruberto, G. 2015. Essential Oil from Piper pedicellatum C. DC. Collected in North-East India. Journal of Essential Oil Bearing Plants, 18: 314-319.

Salleh, W.M.; Kammil, M.F.; Ahmad, F., Sirat, H.M. 2015. Antioxidant and Anti-inflammatory Activities of Essential Oil and Extracts of Piper miniatumi. Natural Product Communications, 10: 2005-2008.
Santana, H.T.; Trindade, F.T.T.; Stabeli, R.G.; Silva, A.A.E.; Militão, J.S.L.T.; Facundo, V.A. 2015. Essential oils of leaves of Piper species display larvicidal activity against the dengue vector, Aedes aegypti (Diptera: Culicidae). Revista Brasileira de Plantas Medicinais, 17: 105-111.

Santos, P.R.D.; Moreira, D.L.; Guimarães, E.F.; Kaplan, M.A.C. 2001. Essential oil analysis of 10 Piperaceae species from the Brazilian Atlantic forest. Phytochemistry, 58: 547-551.

Sperotto, A.R.M.; Moura, D.J.; Péres, V.F.; Damasceno, F.C.; Caramão, E.B.; Henriques, J.A.P.; Saffi, J. 2013. Cytotoxic Mechanism of Piper gaudichaudianum Kunth Essential Oil and its Major Compound Nerolidol. Food and Chemical Toxicology, 57: 57-68

Trindade, A.P.F.; Velozo, L.S.M.; Guimarães, E.F.; Kaplan, M.A.C. 2010. Essential Oil From Organs of Piper truncatum Vell. Journal of Essential Oil Research, 22: 200-202.

Van Den Dool, H.; Kratz, P.D. 1963. A Generalization of the Retention Index System Including Linear Temperature Programmed Gas-Liquid Partition Chromatography. Journal Chromatography A, 11: 463-471.

von Poser, G.L.; Rorig, L.R.; Henriques, A.T. 1994. Aromatic Plants from Brazil. III. The Chemical Composition of Piper gaudichaudianum Kunth and P. mikanianum (Kunth) Steudel Essential Oils. Journal of Essential Oil Research, 6: 337-340.

Woguem, V.; Maggi, F.; Fogang, H.P.; Tapondjoua, L.A.; Womeni, H.M.; Luana, Q. et. al. 2013. Antioxidant, antiproliferative and antimicrobial activities of the volatile oil from the wild pepper Piper capense used in Cameroon as a culinary spice. Natural Product Communications, 8: 1791-1796.

RECEIVED: $07 / 03 / 2018$

ACCEPTED: 28/07/2018

ASSOCIATE EDITOR: Jorge David 